\title{
New Aura Microwave Limb Sounder observations of BrO and implications for $\mathrm{Br}_{\mathrm{y}}$
}

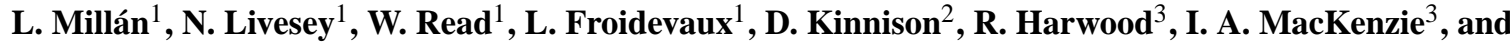 \\ M. P. Chipperfield ${ }^{4}$ \\ ${ }^{1}$ Jet Propulsion Laboratory, California Institute of Technology, Pasadena, California, USA \\ ${ }^{2}$ National Center for Atmospheric Research, Boulder, Colorado, USA \\ ${ }^{3}$ School of GeoSciences, University of Edinburgh, UK \\ ${ }^{4}$ Institute for Climate and Atmospheric Science, University of Leeds, UK
}

Correspondence to: L. Millán (luis.f.millan@jpl.nasa.gov)

Received: 10 December 2011 - Published in Atmos. Meas. Tech. Discuss.: 10 January 2012

Revised: 8 May 2012 - Accepted: 26 June 2012 - Published: 20 July 2012

\begin{abstract}
This paper introduces a new inversion algorithm for retrievals of stratospheric $\mathrm{BrO}$ from the Aura Microwave Limb Sounder. This version is based on the algorithm described by Livesey et al. (2006a) but uses a more realistic atmospheric state to constrain the retrieval. A description of the methodology and an error analysis are presented. Single daily profile precision uncertainty, when taking the ascending-descending (day-night) difference, was found to be up to $40 \mathrm{pptv}$ while systematic error biases were estimated to be less than about 3 pptv. Monthly mean comparisons show broad agreement with other measurements as well as with state-of-the-art numerical models. We infer a 2005 yearly total inorganic $\mathrm{Br}_{\mathrm{y}}$ using the measured MLS BrO to be $20.3 \pm 4.5 \mathrm{pptv}$, which implies a contribution from very short lived substances to the stratospheric bromine budget of $5 \pm 4.5$ pptv.
\end{abstract}

\section{Introduction}

Stratospheric $\mathrm{O}_{3}$ destruction has been a great concern since 1985 when massive $\mathrm{O}_{3}$ loss over the Antarctic spring, the now famous "O $\mathrm{O}_{3}$ hole", was reported (Farman et al., 1985). Extensive research, both theoretical and observational, showed that this $\mathrm{O}_{3}$ depletion was caused by complex chemical processes involving radicals containing chlorine and less abundant bromine. By contrast with chlorine, the stratospheric bromine budget is still not well understood. The fact that it depletes stratospheric $\mathrm{O}_{3}$ much more efficiently than chlorine on a per atom basis (e.g., Sinnhuber et al., 2009) makes this budget an issue of great importance.

Stratospheric inorganic bromine $\left(\mathrm{Br}_{\mathrm{y}}\right)$ sources can be classified as (e.g., Wamsley et al., 1998; Montzka et al., 2003) natural and anthropogenic methyl bromide $\left(\mathrm{CH}_{3} \mathrm{Br}\right)$, manufactured long-lived halons (such as $\mathrm{CBrClF}_{2}$ and $\mathrm{CBr}_{2} \mathrm{~F}_{2}$ ) and a variety of predominantly natural very short lived substances (VSLS) containing bromine (such as $\mathrm{CHBr}_{3}, \mathrm{CH}_{2} \mathrm{Br}_{2}, \mathrm{CH}_{2} \mathrm{ClBr}$ ). These compounds, when transported to the upper troposphere and stratosphere, are converted into inorganic bromine forms $\left(\mathrm{Br}_{\mathrm{y}}=\mathrm{Br}+\mathrm{BrO}+\mathrm{BrONO}_{2}+\mathrm{HOBr}+\mathrm{BrCl}+\mathrm{HBr}\right)$ by photolysis or reactions with $\mathrm{OH}$ radicals (e.g., Pundt et al., 2002).

Part of the reason why the stratospheric bromine budget is not well understood is that, despite many studies, the exact contribution of VSLS to the stratospheric $\mathrm{Br}_{\mathrm{y}}$ is still uncertain; current estimates for the $\mathrm{Br}_{\mathrm{y}}$ loading from VSLS $\left(\mathrm{Br}_{\mathrm{y}}^{\mathrm{VSLS}}\right)$ derived from measurements of stratospheric bromine vary from 3 to 8 pptv WMO (World Meteorological Organization, 2010, Chapt. 1). Furthermore, Salawitch et al. (2005) and Feng et al. (2007) have shown that even only a few pptv of additional bromine increases $\mathrm{O}_{3}$ depletion, especially during times of elevated stratospheric aerosol loading due to volcanic activities.

In this paper we introduce a new dataset of global observations of stratospheric BrO from the Aura Microwave Limb Sounder (MLS) instrument. BrO is the most abundant $\mathrm{Br}_{\mathrm{y}}$ species during daytime and it has been used to estimate the stratospheric $\mathrm{Br}_{\mathrm{y}}$ using photochemical models. We compare 
this new dataset with previous MLS BrO products, with expectations, and with other datasets. In addition, we infer a new estimate for the $\mathrm{Br}_{\mathrm{y}}^{\mathrm{VSLS}}$ loading.

\section{MLS BrO observations}

Aura was launched into a polar sun synchronous orbit in July 2004. As part of its payload, the MLS instrument measures thermal limb emission in the millimeter and submillimeter wavelength range. MLS scans the Earth's limb from the surface to about $95 \mathrm{~km}$ roughly 3500 times per day. It observes between $82^{\circ} \mathrm{S}$ and $82^{\circ} \mathrm{N}$ providing daily near-global coverage. In general, most measurements are made at about 01:45 or 13:45 local solar time (LST); the exceptions are the measurements near the poles where the observation transition changes between daytime and nighttime conditions or vice versa. A detailed description of the Aura MLS instrument is given by Waters et al. (1999) and Waters et al. (2006).

MLS collects the atmospheric radiation with a $1.6 \mathrm{~m}$ antenna and directs it onto four heterodyne radiometers covering spectral regions near $118 \mathrm{GHz}, 191 \mathrm{GHz}, 240 \mathrm{GHz}$ and $640 \mathrm{GHz}$ (a fifth radiometer located at $2.5 \mathrm{THz}$ is fed by a separate antenna). The outputs of the $\mathrm{GHz}$ radiometers are analyzed by 22 filter banks and 4 digital autocorrelator spectrometers (DACS). Each filter bank targets one molecule in particular, although MLS is a double sideband receiver that reports a combined signal from two separate spectral regions; where possible, the overlapping regions were chosen with no strong lines.

MLS observes two sets of $\mathrm{BrO}$ emission lines within the $640 \mathrm{GHz}$ radiometer with two filter banks, one around $650 \mathrm{GHz}$ and the other around $625 \mathrm{GHz}$. Figure 1 shows observations from these filter banks. In both cases the $\sim 0.2 \mathrm{~K}$ $\mathrm{BrO}$ signal overlaps with $\mathrm{a} \sim 2 \mathrm{~K} \mathrm{O}_{3}$ signal. Taking the ascending-descending (day-night) difference removes the $\mathrm{O}_{3}$ signal, which does not have a diurnal variation at these altitudes, revealing the strongly diurnal nature of $\mathrm{BrO}$. Furthermore, the $\sim 0.2 \mathrm{~K} \mathrm{BrO}$ signal is well below the individual measurement precision of about $4 \mathrm{~K}$, hence, significant averaging (as in Fig. 1) is required to obtain a useful $\mathrm{BrO}$ signal.

\section{Retrieval methodology}

To date, two different approaches to do the required averaging and inversion have been implemented. The standard production approach (MLS L2) is simply to retrieve the $\mathrm{BrO}$ abundances for every limb sequence, as is done for all MLS products, and then average the individual $\mathrm{BrO}$ profiles (see Kovalenko et al., 2007). This approach produces approximately 3500 profiles daily with a $10^{\circ}$ monthly zonal mean precision of $\sim 4$ pptv. These retrieval algorithms are described in detail by Livesey et al. (2006b). In summary, the well known optimal estimation technique (Rodgers, 2000) is used employing a two-dimensional approach that uses

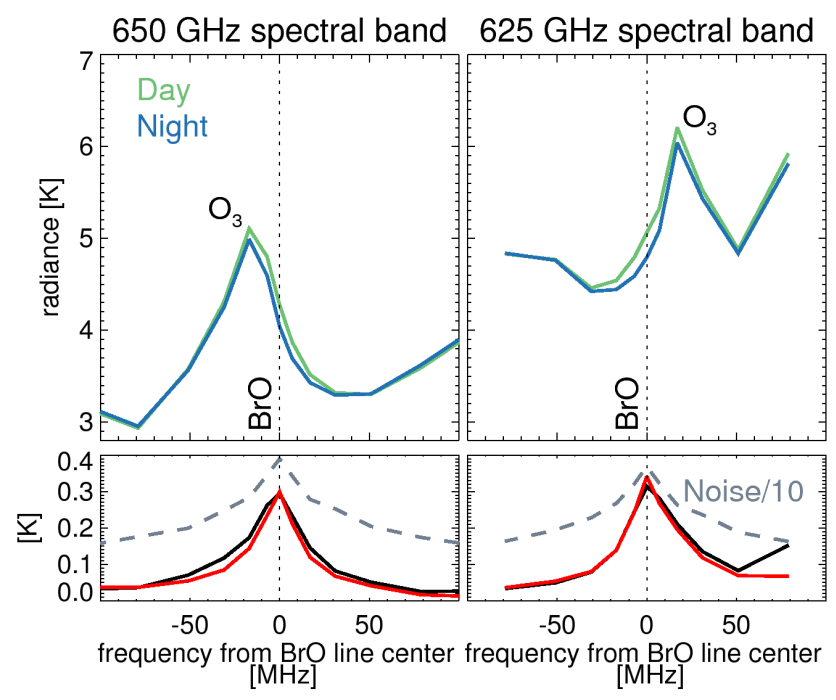

Fig. 1. Top: average MLS radiance as detected in the 650 and $625 \mathrm{Ghz}$ spectral bands sorted into day (blue) and night (green) time measurements. Average is from $55^{\circ} \mathrm{S}$ and $55^{\circ} \mathrm{N}$ and for limb tangents from 10 to $4.6 \mathrm{hPa}$ for 2005 . Bottom: differences between the ascending and descending (mainly day and mainly night) measurements (black) reveals the $\mathrm{BrO}$ spectral signature. The red lines represent the spectrum simulated by using the new averaged $\mathrm{BrO}$ retrieved value introduced here. The dashed gray line is $1 / 10$ of the expected single scan noise.

consecutive scans covering overlapping regions of the atmosphere along the sub-orbital track. In the current version of this approach (version 3.3), the $\mathrm{BrO}$ abundances are retrieved simultaneously with several other molecules $\left(\mathrm{ClO}, \mathrm{HCl}, \mathrm{O}_{3}\right.$, $\mathrm{HO}_{2}, \mathrm{HOCl}, \mathrm{CH}_{3} \mathrm{CN}, \mathrm{HNO}_{3}, \mathrm{SO}_{2}$ and $\mathrm{CH}_{3} \mathrm{Cl}$ ) using all the available radiances in the $640 \mathrm{GHz}$ radiometer. The temperature, pressure, and pointing information are retrieved in a previous processing stage.

The second approach, performed "off-line" (MLS OL1), is to create daily zonal mean radiances from which vertical $\mathrm{BrO}$ abundances can then be retrieved. This approach was implemented by Livesey et al. (2006a). In short, limb scans from a particular day are collocated into $10^{\circ}$ latitude average bins dividing them into ascending (mostly daytime) and descending (mostly nighttime) halves of the orbit. Radiances are binned onto a vertical grid of 6 surfaces per decade change in pressure $(\sim 3 \mathrm{~km})$ using the limb tangent pressure from the standard production data. Then, this second approach retrieval uses a one-dimensional optimal estimation technique producing a pair of zonal mean abundances for each day (one ascending and one descending) giving a $10^{\circ}$ monthly zonal mean precision of $\sim 3.5 \mathrm{pptv}$. This algorithm retrieves $\mathrm{BrO}$, temperature and some overlapping species simultaneously from only the $650 \mathrm{GHz}$ and $625 \mathrm{GHz}$ filter banks.

For this study, a new "off-line" algorithm has been developed (MLS OL2). It is similar to the one described by Livesey et al. (2006a) with the following differences: (1) this 


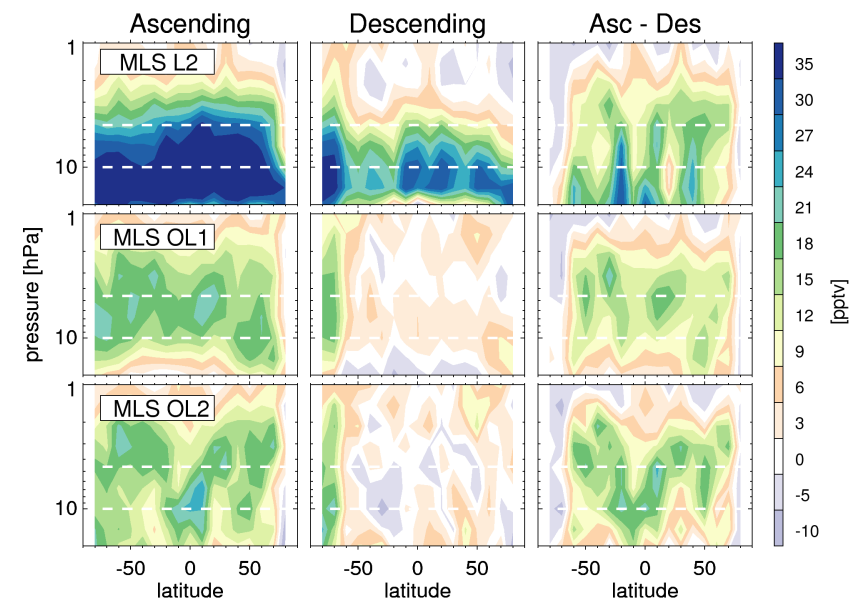

Fig. 2. Monthly zonal mean for January 2005 of MLS BrO observations for the three versions discussed in the text for ascending (mainly daytime) and descending (mainly nighttime) phases of the orbit. The dataset MLS L2 is the standard production algorithm described by Kovalenko et al. (2007), MLS OL1 is the "off-line" algorithm described by Livesey et al. (2006a) and MLS OL2 is the dataset introduced here. The region between the white dashed lines indicates where the MLS ascending-descending difference are suitable for scientific use.

retrieval assumes averaged temperature, $\mathrm{O}_{3}$, and $\mathrm{HNO}_{3}$ data from the standard production algorithm to give the most realistic atmospheric representation available; (2) minor overlapping species are retrieved independently for each band to avoid inconsistencies due to different systematic errors; and (3) the channels used in each $\mathrm{BrO}$ spectral band were more carefully selected. This selection was performed by searching for consistency in the $\mathrm{BrO}$ abundances retrieved from each band.

As for the MLS L2 and MLS OL1, the optimal estimation approach (Rodgers, 2000) is used. In this study, the a priori mixing ratio for $\mathrm{BrO}$ daytime is $\sim 11 \mathrm{pptv}$ from 10 to $4.6 \mathrm{hPa}$, decreasing monotonically with pressure up to a value of $\sim 4$ pptv at $1 \mathrm{hPa}$; the a priori mixing ratio for $\mathrm{BrO}$ nighttime is around $\sim 1 \mathrm{pptv}$ from $10 \mathrm{hPa}$ to $4.6 \mathrm{hPa}$ increasing monotonically with pressure up to a value of $\sim 5 \mathrm{pptv}$ at $1 \mathrm{hPa}$. The uncertainties in these a priori are assumed to be $200 \mathrm{pptv}$ allowing the information to arise mostly from the measurements. In addition to this constraint, a Twomey-Tikhonov regularization was used to reduce noise and smooth the profile at the expense of some vertical resolution.

For comparison, Fig. 2 shows monthly zonal means for the three versions previously discussed. MLS L2 exhibits a large negative offset for pressures larger than $10 \mathrm{hPa}$. The two "offline" algorithms display similar behavior to each other.

As previously discussed by Livesey et al. (2006a) and Kovalenko et al. (2007), negligible $\mathrm{BrO}$ abundances are expected at mid and equatorial latitudes for pressures larger than $\sim 4 \mathrm{hPa}$ during night, hence non-zero descending $\mathrm{BrO}$

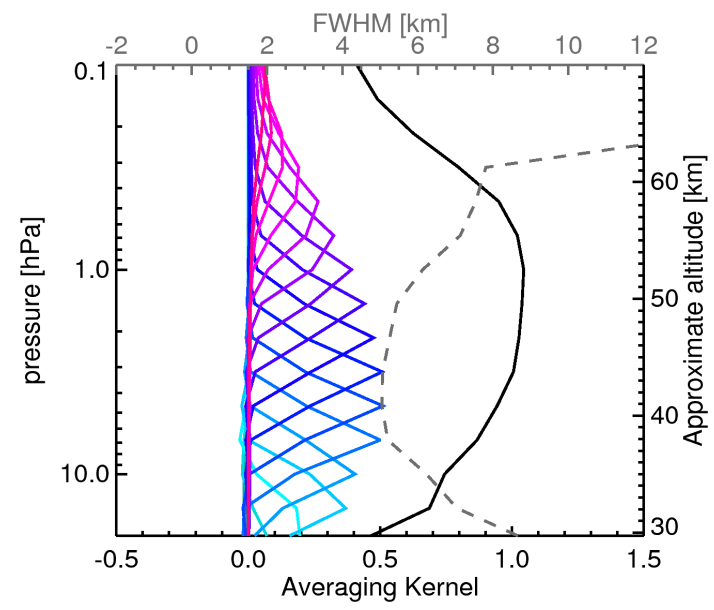

Fig. 3. Averaging kernels for the retrieval of $\mathrm{BrO}$ mixing ratio at the equator (those at other latitudes are very similar). The black line is the integrated area under each kernel: values near unity indicate that most information was provided by the measurements while lower values indicate that the retrieval was influenced by the a priori. The dashed gray line is a measure of the vertical resolution of the retrieved profile (derived from the full width at half maximum (FWHM) of the averaging kernels approximately scaled into kilometers).

retrieved abundances at these pressure levels indicate biases caused by improperly modeled systematic errors. These systematic errors are expected to be constant irrespective of the solar illumination, hence, taking an ascending-descending $\mathrm{BrO}$ difference significantly reduces them. This difference is therefore a better estimate of the daytime $\mathrm{BrO}$ than taking just the face values of the ascending set. Unfortunately, this restricts the usable data of any of the MLS BrO products to between $50^{\circ} \mathrm{S}$ and $50^{\circ} \mathrm{N}$, which ensures that the LST is either day or night for the ascending and descending part of the orbit, and with a minimum usable pressure of $4.6 \mathrm{hPa}$, which ensures that the nighttime $\mathrm{BrO}$ is negligible. As pointed out by Kovalenko et al. (2007), it may be possible to characterize these systematic errors in order to reduce the biases in the polar regions and extend the coverage of the MLS data, however this is outside the scope of this study.

\subsection{Vertical resolution}

Typical averaging kernels for the MLS OL2 retrieval of $\mathrm{BrO}$ are shown in Fig. 3. They describe how the true state of the atmosphere has been distorted by the retrieval at each pressure level. The half width of each kernel provides a measure of the vertical resolution of the retrieval, and its area (the integrated kernel) indicates the dependence on the a priori. As shown, the new $\mathrm{BrO}$ product has a vertical resolution of about $5 \mathrm{~km}$ and the retrieval was not significantly influenced by the a priori between 10 and $1 \mathrm{hPa}$. For pressure levels greater than $10 \mathrm{hPa}$, the retrieval is vastly influenced by the a priori and hence not recommended for scientific use. 


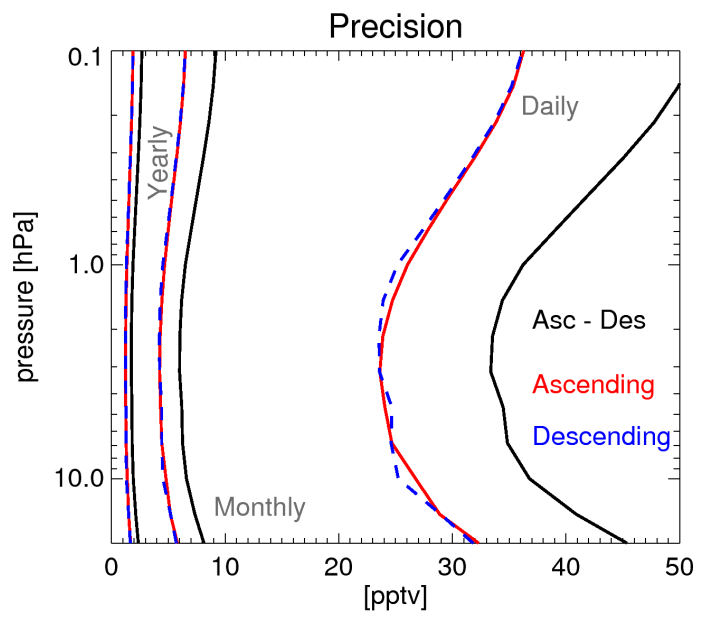

Fig. 4. Expected precision for a daily, monthly and yearly $10^{\circ}$ latitude bin. The "Asc - Des" precision is the root sum square of the ascending and descending values.

\subsection{Error assessment}

The total error in the retrieved product arises from the sum of the random and systematic errors. The random errors (the expected precision) are determined by the random noise in the radiance measurements propagated through the retrieval system while the systematic errors arise from forward model uncertainties, instrumental issues, and retrieval approximations.

Figure 4 displays the expected precision for daily, monthly, and yearly profiles over a $10^{\circ}$ latitude bin. The ascending and descending precisions are very similar. Over a pressure range between 10 and $4.6 \mathrm{hPa}$, the daily precision for a $10^{\circ}$ latitude bin either ascending or descending is around $25 \mathrm{pptv}$, dropping to $5 \mathrm{pptv}$ and $\sim 1.8 \mathrm{pptv}$ for monthly and yearly averages, respectively. The precision in the ascending-descending difference is up to 40 pptv daily while the monthly and yearly precisions drop to $\sim 7$ and $\sim 2.5$ pptv. Although significant averaging, such as months or even years, is needed to be able to get a usable $\mathrm{BrO}$ estimate, this retrieval uses daily zonal mean radiances instead of weekly or monthly to give the user the flexibility to average different combination of days as needed.

Figure 5 summarizes the impact of the dominant systematic uncertainties for the BrO MLS OL2 measurements. Two methods have been used to quantify the impact of the systematic errors. In the first method, the errors are estimated by an end-to-end simulation of the retrieval algorithm. First, for each systematic error, a perturbed set of radiance simulations is generated for a whole day ( $\sim 3500$ profiles) using a model atmosphere (a complete list and more detailed discussion of the systematic errors is given by Read et al., 2007, Appendix A). These simulated radiances were binned in $10^{\circ}$ latitude bins and gridded onto a 6 surface per decade pressure

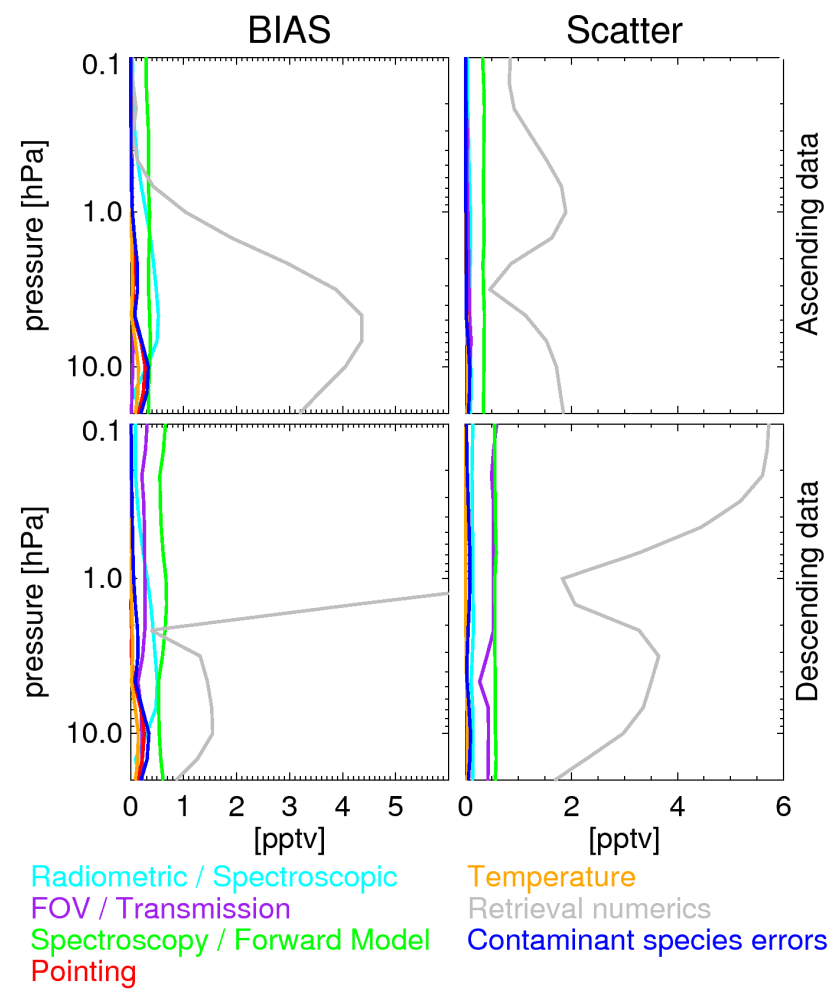

Fig. 5. Estimated impact of various families of systematic errors on the MLS OL2 $\mathrm{BrO}$ observations. Cyan lines correspond to uncertainties in the MLS radiometric and spectral calibration. Magenta lines denote uncertainties associated with the MLS FOV and antenna transmission efficiency. Green lines denote errors in the spectroscopic databases and due to the forward model approximations. The impact of the uncertainties in the MLS pointing are depicted by the red lines. The yellow lines corresponds to errors in the retrieved MLS temperature, while the blue lines show the impact of the retrieved errors in contaminant species. Errors due to retrieval formulation are shown in gray. The top panel corresponds to the ascending part of the orbit while the lower panel corresponds to the descending part. The left panel shows the possible biases and the right panel shows the additional scatter introduced by each family of systematic errors.

grid and then run through the "off-line" retrieval algorithm as normal. Each of the retrieved results is compared to the retrieved $\mathrm{BrO}$ from an unperturbed run, as a measure of the impact of a given systematic error source. Each perturbation corresponds to either $2 \sigma$ estimates of uncertainties in the relevant parameter or an estimate of their maximum reasonable error based on instrument knowledge. Furthermore, the difference between the unperturbed run and the "true" model atmosphere estimates the errors due to the retrieval itself (i.e. "retrieval numerics").

A second method is used for the, typically small, error sources that are difficult to quantify in an end-to-end exercise. Examples of these error sources include, but are not limited to, errors due to the filter position uncertainties, errors 


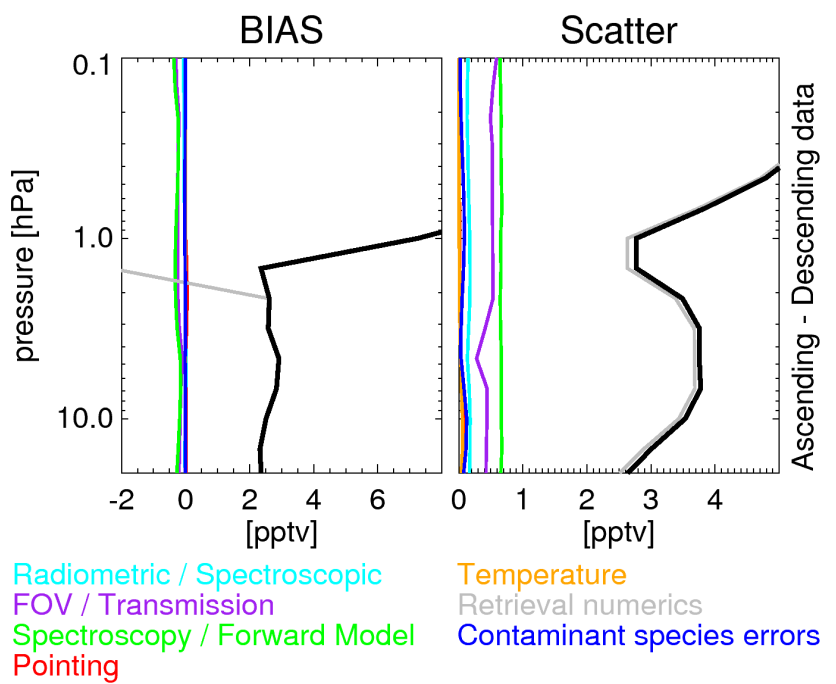

Fig. 6. Estimated impact of various families of systematic errors for ascending-descending MLS OL2 BrO observations. The left panel shows the possible biases (the difference of the ascendingdescending biases in Fig. 5) and the right panel shows the additional scatter introduced by each family of systematic errors (the root sum squares of the scatter in Fig. 5). The black lines are the root sum squares of all the biases or the scatters shown.

due to the spectrometer nonlinearity and errors due to the interaction of spectrometers sharing the same power supply, etc.). Their impact is quantified with a simple analytical model of the MLS measurement system (Read et al., 2007, Auxiliary material).

Throughout most of the profile (either for the ascending or the descending case), the main source of systematic bias arises from retrieval numerics. While unsatisfactory, this is somewhat expected due to strong overlapping $\mathrm{O}_{3}$ signals in contrast to the small $\mathrm{BrO}$ signature, in addition to the smoothing inherent in the retrieval algorithm. Note that the contaminant species errors do not quantify the effect of the overlapping species per se but rather the uncertainty in their mixing ratio.

As already mentioned, the effects of the systematic biases can be diminished by subtracting the nighttime retrieved values from the daytime (taking advantage of the pronounced $\mathrm{BrO}$ diurnal variation below $\sim 4 \mathrm{hPa}$ where negligible $\mathrm{BrO}$ is expected during night). Figure 6 summarizes the impact of several systematic uncertainties for the MLS OL2 BrO measurements when the ascending-descending differences are used as an indicator of daytime BrO. Observe that the additional noise-induced scatter introduced by the ascendingdescending differences will average down, since averages over several days are needed to obtain a useful $\mathrm{BrO}$ signal.

The advantage of using daily zonal mean radiances can be appreciated by comparing the systematic error estimates presented here against the estimates performed by Kovalenko et al. (2007); while in the standard approach, the aggregate

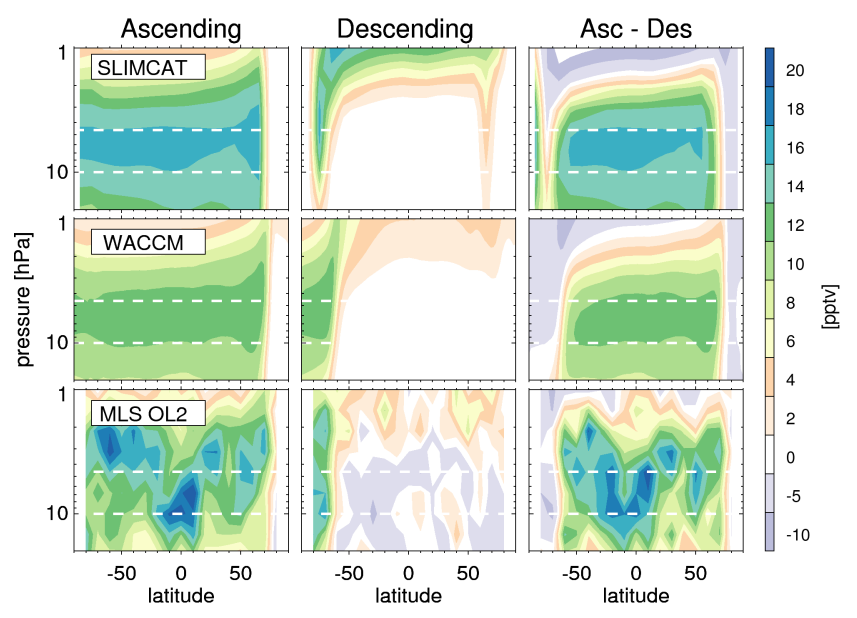

Fig. 7. Monthly zonal mean of MLS BrO observations for ascending and descending phases of the orbits as well as the SLIMCAT and WACCM models for January 2005. To alleviate biases in the MLS BrO data, the ascending-descending differences are used as a measure of daytime $\mathrm{BrO}$ for pressure greater than $4.6 \mathrm{hPa}$ where the nighttime $\mathrm{BrO}$ is expected to be zero. The region between the white dashed lines indicates where the MLS ascending-descending difference are suitable for scientific use.

systematic errors between the 10 to $4.6 \mathrm{hPa}$ region vary from 15 to $30 \mathrm{pptv}$, when using daily zonal mean radiances systematic errors are always less than $\sim 3$ pptv.

\section{Comparisons with numerical models}

Figures 7 and 8 show monthly mean comparisons between the MLS OL2 data and two state-of-the-art numerical models: SLIMCAT and WACCM. Two months were compared, January and July 2005, in order to compare BrO at two points in the seasonal cycle.

SLIMCAT (Chipperfield, 1999, 2006) is an off-line chemical transport model (CTM). For this analysis it was run driven by the European Centre for Medium-Range Weather Forecasts (ECMWF) winds and temperature fields with a horizontal resolution of $2.8^{\circ} \times 2.8^{\circ}$ and a vertical coordinate that, in the stratosphere, is essentially based on isentropic surfaces with a spacing of approximately $1.2 \mathrm{~km}$. The model results were sampled at the same location and time as the MLS individual profiles. Reaction rates were taken from the JPL 2002 recommendations (Sander et al., 2003) with the added reaction (Soller et al., 2001)

$\mathrm{BrONO}_{2}+\mathrm{O} \rightarrow \mathrm{BrO}+\mathrm{NO}_{3}$.

The Whole Atmosphere Community Climate Model (WACCM), Version 4 is a fully interactive chemistry climate model, where the radiatively active gases affect heating and cooling rates and therefore dynamics (Garcia et al., 2007). For this analysis the model was run with a horizontal resolution of $1.9^{\circ} \times 2.5^{\circ}$ in latitude and longitude using 


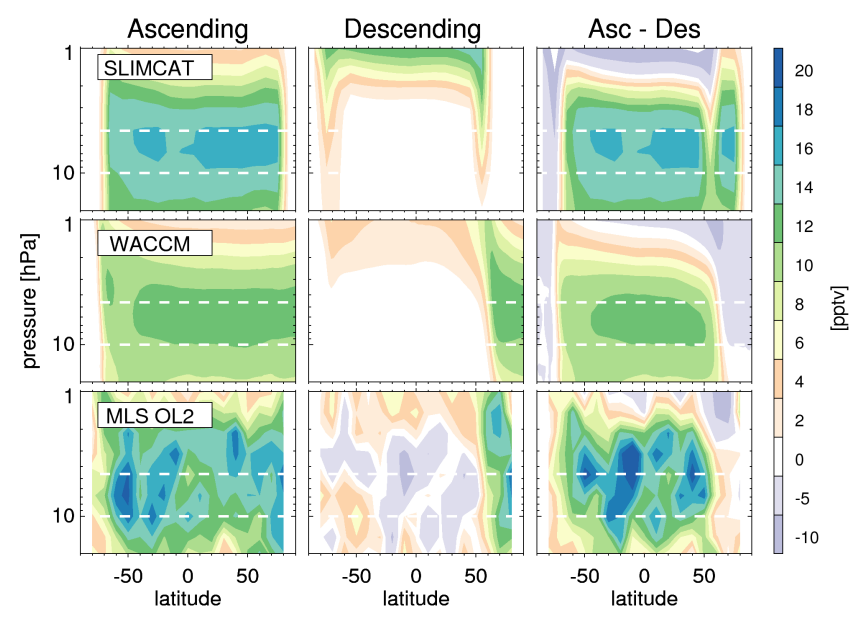

Fig. 8. Same as Fig. 7, except that the data correspond to July instead of January 2005.

meteorological fields derived from the Goddard Earth Observing System 5 (GEOS-5) analyzes, and a vertical coordinate purely isobaric in the stratosphere with a variable spacing of 1.1 to $1.75 \mathrm{~km}$. This new capability of this model is described by Lamarque et al. (2012) and allows WACCM to perform as a chemical transport module facilitating the comparisons with observations. The chemical module of WACCM is based on the 3-D chemical transport Model of Ozone and Related Tracers, Version 4 (Kinnison et al., 2007). Reactions rates were taken from the JPL 2006 recommendations (Sander et al., 2006) which includes reaction R1. For the most part, the only relevant difference between the JPL 2006 and the JPL 2002 recommendations is that the uncertainties of the reactions were reduced in many cases, particularly at low temperatures. There are no noteworthy changes for the key reactions involved in these model runs in the latest JPL recommendations (Sander et al., 2011).

As shown in Figs. 7 and 8, MLS OL2 data display the distinct $\mathrm{BrO} \sim 10 \mathrm{hPa}$ diurnal variation not only at mid and equatorial latitudes but also at the poles with negligible $\mathrm{BrO}$ abundances around the polar winter regions (where there is constant nighttime) and higher $\mathrm{BrO}$ values in the polar summer regions (where there is constant daytime).

\section{Comparisons with other datasets}

\subsection{Diurnal variation}

Due to the diurnal nature of the $\mathrm{BrO}$ abundances (see Fig. 9), comparisons between measurements with different local times must be made with caution. In this study, the datasets used were scaled from its local time to that of the MLS scene using the tabulated output from a photochemical box model (Prather, 1992; McLinden et al., 2000). This model was driven by climatological temperature and $\mathrm{O}_{3}$. The

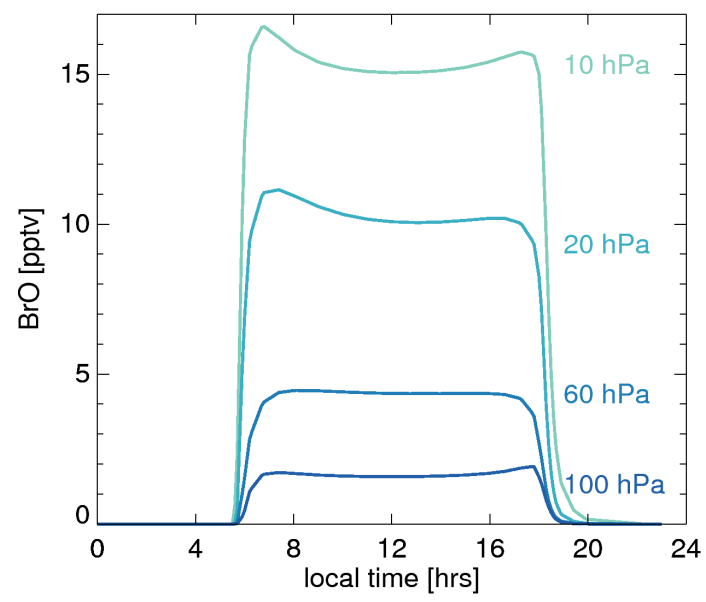

Fig. 9. Photochemical box model simulation of $\mathrm{BrO}$ at different pressure levels in the equatorial region computed for mid-January.

look-up tables are given as function of latitude in $2.5^{\circ}$ increments, every 1 st, 11 th and 21 st of a given month, in a pressure grid with 8 surfaces per decade from the surface up to $0.0177 \mathrm{hPa}$ interpolated from 25 altitude levels from 10 to $58 \mathrm{~km}$, and with up to $34 \mathrm{SZA} / \mathrm{LST}$ points per table.

The scaling was performed using

$$
\begin{aligned}
\mathrm{BrO}^{\mathrm{obs}}\left(t_{\mathrm{MLS}}, p\right)= & \mathrm{BrO}^{\mathrm{obs}}\left(t_{\mathrm{obs}}, p\right)\left(\frac{\mathrm{BrO}^{\mathrm{mod}}\left(t_{\mathrm{MLS}}, p\right)}{\mathrm{BrO}^{\mathrm{mod}}\left(t_{\mathrm{obs}}, p\right)}\right) \\
& \left(\frac{\mathrm{NO}_{\mathrm{y}}^{\mathrm{MLS}}\left(t_{\mathrm{MLS}}, p\right)}{\mathrm{NO}_{\mathrm{y}}^{\mathrm{mod}}\left(t_{\mathrm{MLS}}, p\right)}\right)
\end{aligned}
$$

where $\mathrm{BrO}^{\text {obs }}$ and $\mathrm{BrO}^{\text {mod }}$ are the $\mathrm{BrO}$ volume mixing ratio of the observations and the photochemical model at a given local time $t$, and at a particular pressure level $p$; where $\mathrm{NO}_{\mathrm{y}}^{\mathrm{MLS}}$ is the $\mathrm{NO}_{\mathrm{y}}$ volume mixing ratio derived from the $\mathrm{N}_{2} \mathrm{O}$ MLS measurements using the relationships described by Sugita et al. (1998) and $\mathrm{NO}_{\mathrm{y}}^{\text {mod }}$ is the volume mixing ratio used in the photochemical model. In Eq. (1), the BrO ratio is used to map the measurements to the MLS local time, and the $\mathrm{NO}_{\mathrm{y}}$ ratio is used to constrain the $\mathrm{NO}_{2}$ through the $\mathrm{NO}_{\mathrm{y}}$ concentration. This last ratio is needed because, as discussed in Sioris et al. (2006), accurate knowledge of the $\mathrm{NO}_{2}$ concentration is needed for computation of scientifically useful photochemical scaling factors of $\mathrm{BrO}$.

Uncertainties in the scaling factors were estimated by performing a sensitivity analysis, individually varying the abundances of $\mathrm{O}_{3}$, temperature and $\mathrm{NO}_{\mathrm{y}}$. The overall uncertainties, over the pressure range where the MLS OL2 data is considered scientifically useful, are about $20 \%$. This error mainly reflects the uncertainty in a $10^{\circ}$ monthly zonal mean $\mathrm{N}_{2} \mathrm{O}$ MLS concentration (random and systematic errors included). In this paper, whenever the data is scaled to another local time, this modeling error is added to the total error. 


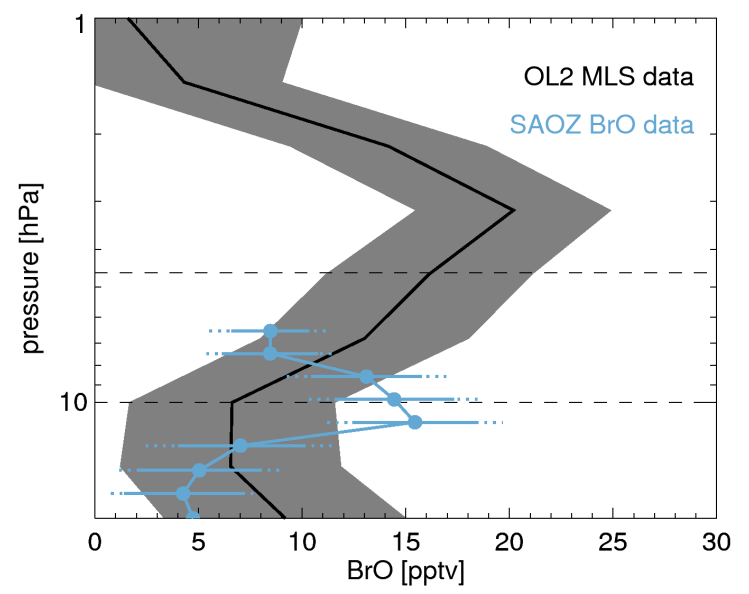

Fig. 10. Comparison of BrO MLS ascending-descending difference and SAOZ-BrO data from 24 August 2004 at $52^{\circ} \mathrm{N}$. The SAOZ$\mathrm{BrO}$ data have been scaled to the local time of the MLS observations. Note that the peak around $10 \mathrm{hPa}$ is a consequence of this scaling. The MLS data corresponds to the average of the 19th to the 29th of August from 2004 to 2011 for the $10^{\circ}$ latitude bin centered at $50^{\circ} \mathrm{N}$. The MLS errors (gray shaded region) represents a combination of precision and accuracy, the SAOZ error bars indicate precision (solid) and precision plus the scaling uncertainty (dashed). The region between the black dashed lines indicates where the MLS ascending-descending difference are suitable for scientific use.

\subsection{Comparison with balloon flights}

Through the years there have been a number of balloon-borne measurements of stratospheric BrO, i.e. Pundt et al. (2002) and Dorf et al. (2006); unfortunately, only one of the flights having publicly available data coincides with the latitudinal and vertical range of the MLS OL2 measurements. Figure 10 compares BrO MLS OL2 with data by the SAOZ-BrO (Systeme dAnalyse par Observations Zenithales) balloon-borne instrument (Pundt et al., 2002), a UV-visible spectrometer designed for the measurement of $\mathrm{BrO}$ by solar occultation in the $320-400 \mathrm{~nm}$ spectral range. This profile was taken on 24 August 2004 in Vascoy, Canada $\left(52^{\circ} \mathrm{N}\right)$. Overall, inside the vertical range over which the scientifically useful MLS ascending-descending difference measurement overlaps with the SAOZ-BrO data, the $\mathrm{BrO}$ estimates agree within their uncertainties.

\subsection{Satellite intercomparison}

Comparison of monthly means were made with those of the Scanning Imaging Absorption spectrometer for Atmospheric Cartography (SCIAMACHY) and the Optical Spectrograph and Infrared Imaging System (OSIRIS) instruments.

SCIAMACHY, on board the ENVISAT satellite launched in March 2002, is a spectrometer measuring solar radiation in the ultraviolet, the visible and the near infrared spectral regions (240-2380 nm) at a moderate spectral resolution

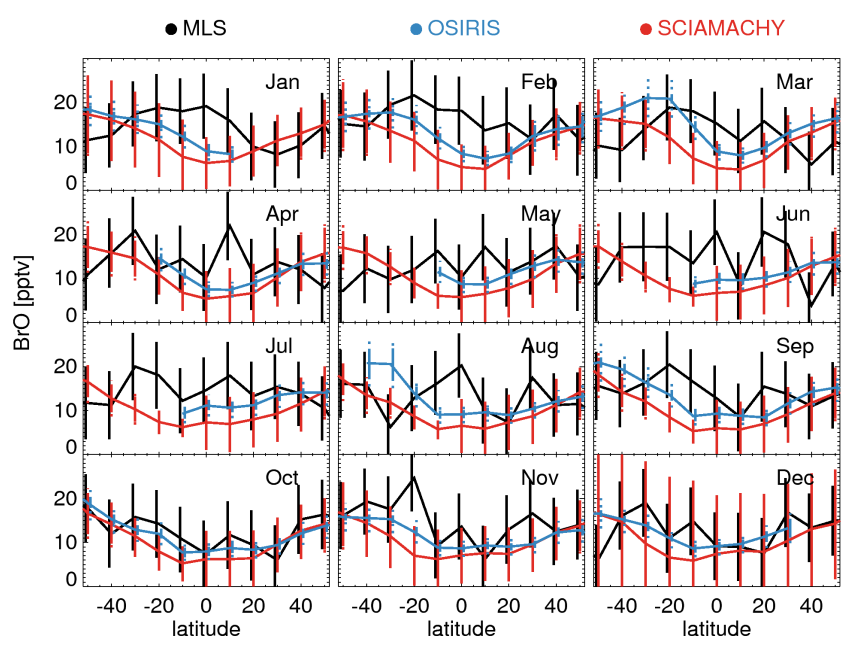

Fig. 11. Comparison between MLS (Asc-Des), OSIRIS and SCIAMACHY BrO observations at $10 \mathrm{hPa}$, for 2005 . The OSIRIS and SCIAMACHY means have been scaled to the local time of the MLS observations. The MLS errors represents a combination of precision and accuracy, the OSIRIS and SCIAMACHY error represent precision (solid) and precision plus scaling uncertainty (dashed). The large SCIAMACHY error bars in December are due to the few number of days available for this particular month.

$(0.2 \mathrm{~nm}-1.5 \mathrm{~nm})$ either in nadir, solar/lunar occultation or limb viewing modes. These viewing modes are used during each orbit to retrieve tropospheric, stratospheric and mesospheric composition (Bovensmann et al., 1999). In this study we used the stratospheric $\mathrm{BrO}$ retrievals from IUP Bremen (Rozanov et al., 2011), in particular version 3.2. These measurements have a LST of 10:00 and a vertical resolution of about $3 \mathrm{~km}$.

OSIRIS is on board the ODIN satellite launched in February 2001. From launch to April 2007, the Odin satellite was a multipurpose mission which alternated between astronomical and atmospheric measurements in one day bins (Lewellyn et al., 2004). Since April 2007, Odin has been a full-time atmospheric satellite. OSIRIS measures spectra across the visible range from $274 \mathrm{~nm}$ to $810 \mathrm{~nm}$ every $0.3 \mathrm{~nm}$ using diffraction gratings. It scans the atmosphere from around 7 to 65 or $90 \mathrm{~km}$, depending on the observing mode with an irregular vertical resolution. These measurements have LST of either $06: 00$ or 18:00. In this study we used the stratospheric $\mathrm{BrO}$ retrievals described by McLinden et al. (2010), this $\mathrm{BrO}$ product has a vertical resolution varying from 3 to $5 \mathrm{~km}$.

Unfortunately, these three datasets only overlap at one pressure level, hence Fig. 11 show a BrO comparison between MLS OL2, OSIRIS AM and SCIAMACHY for 2005 only at $10 \mathrm{hPa}$. In general, MLS seems to have a positive bias, however, these three datasets still agree most of the time within their uncertainties. The apparent latitudinal structure with a minimum in the tropics in the SCIAMACHY and OSIRIS AM datasets, is a consequence of the photochemical 


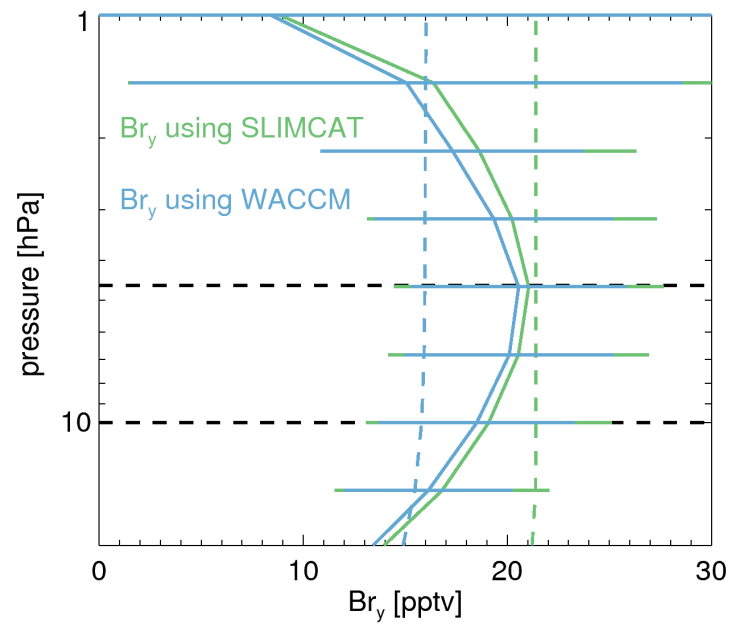

Fig. 12. Average $B r_{y}$ inferred from MLS data using the SLIMCAT (green) and the WACCM (blue) models as described by Eq.(2). Average is for the year 2005. The error bars reflect a combination of the measurement errors, the systematic errors and the kinetics errors. For comparison, the dashed lines show the SLIMCAT (green) and WACCM (blue) modeled values. The region between the black dashed lines indicates where the MLS ascending-descending difference are suitable for scientific use.

scaling factor; in particular due to the $\mathrm{NO}_{2}$ correction. Without this correction, the SCIAMACHY and OSIRIS dataset does not show any latitudinal gradient settling around 12 and 15 pptv, respectively, just between the values predicted by the WACCM and SLIMCAT models (see Figs. 7 and 8).

\section{Implications for total $\mathrm{Br}_{\mathrm{y}}$}

From MLS OL2 $\mathrm{BrO}$ measurements, $\mathrm{Br}_{\mathrm{y}}$ can be inferred approximately from chemical models using the expression

$\mathrm{Br}_{\mathrm{y}}^{\mathrm{MLS}}=\mathrm{BrO}^{\mathrm{MLS}}\left(\frac{\mathrm{Br}_{\mathrm{y}}^{\mathrm{MODEL}}}{\mathrm{BrO}^{\mathrm{MODEL}}}\right)$.

Figure 12 shows average $\mathrm{Br}_{\mathrm{y}}$ profiles obtained using the WACCM and the SLIMCAT models. The error bars shown represent a combination of the uncertainty due to the measured $\mathrm{BrO}$ (precision plus systematic errors) and the uncertainty in the kinetics used to compute the scaling factor. This last uncertainty was assumed to be $\sim 18 \%$, as derived by Sioris et al. (2006) and Hendrick et al. (2008). In addition, it also shows the WACCM and SLIMCAT $\mathrm{Br}_{\mathrm{y}}$ for comparison. These profiles are an average over $50^{\circ} \mathrm{S}$ and $50^{\circ} \mathrm{N}$ for the year 2005. Part of the difference between these profiles is that WACCM Bry loading only includes the sum of $\mathrm{CH}_{3} \mathrm{Br}$ and long-lived halons while SLIMCAT includes those two sources plus VSLS. As can be seen, the two $\mathrm{Br}_{\mathrm{y}}^{\mathrm{MLS}}$ estimates are in excellent agreement. These two yearly profiles of $\mathrm{Br}_{\mathrm{y}}^{\mathrm{MLS}}$ correspond to column estimates of stratospheric

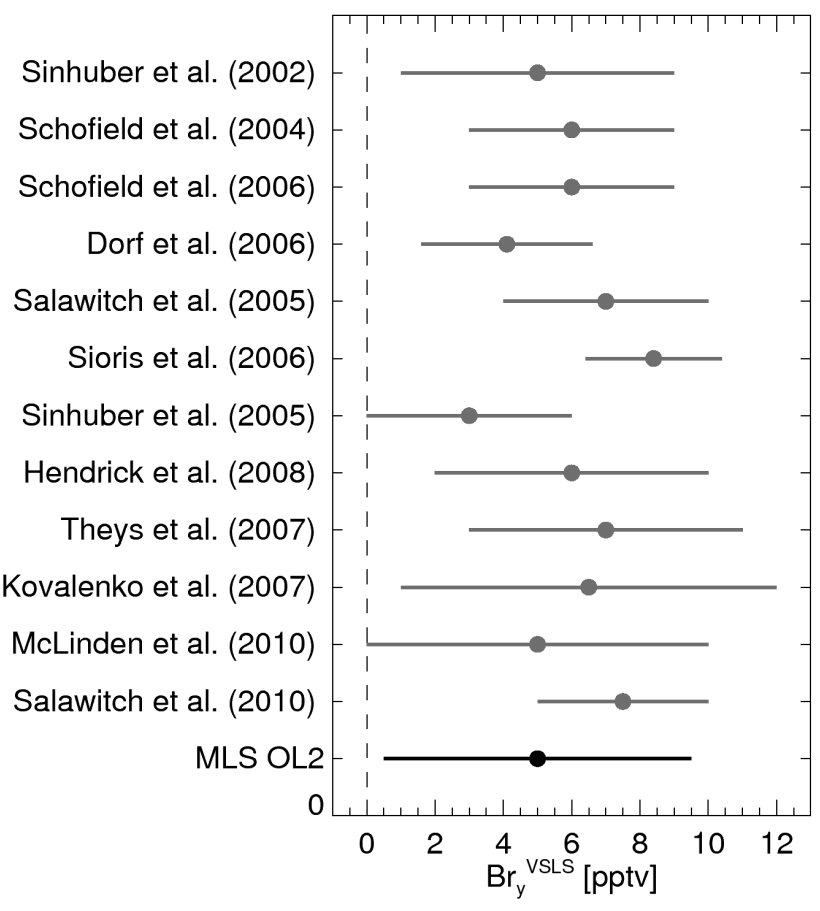

Fig. 13. Estimates of $\mathrm{Br}_{\mathrm{y}}$ from VSLS $\left(\mathrm{Br}_{\mathrm{y}}^{\mathrm{VSLS}}\right.$ ) contribution to stratospheric bromine derived from $\mathrm{BrO}$ measurements as discussed in chapter 1 of WMO (2010) (gray lines) plus the $\mathrm{Br}_{\mathrm{y}}^{\mathrm{VSLS}}$ estimate made in this study (black line).

$\mathrm{Br}_{\mathrm{y}}$ of $20 \pm 4.5 \mathrm{pptv}$ and $20.6 \pm 4.5 \mathrm{pptv}$ (calculated over the pressure surfaces from 10 to $4.6 \mathrm{hPa}$ ) for the data derived with the WACCM and the SLIMCAT model, respectively. Since the two estimates are similar we assume the $\mathrm{Br}_{\mathrm{y}}^{\mathrm{MLS}}$ final estimate to be $20.3 \pm 4.5$ pptv.

Using a yearly mean of the MLS L2 $\mathrm{N}_{2} \mathrm{O}$ measurements between 10 and $4.6 \mathrm{hPa}$ for 2005 , and the correlation between $\mathrm{N}_{2} \mathrm{O}$ and mean age described by Engel et al. (2002), we estimated the age of this air to be $5 \pm 1$ years. According to Montzka et al. (2003), tropospheric $\mathrm{CH}_{3} \mathrm{Br}$ and longlived halons, the other two $\mathrm{Br}_{\mathrm{y}}$ sources besides VSLS, contributed $15.6 \mathrm{pptv}$ to the total bromine at that time. This implies that the new MLS OL2 retrievals suggest a $5 \pm 4.5$ VSLS contribution to $\mathrm{Br}_{\mathrm{y}}$. In the Montzka et al. (2003) total bromine estimate, to account for the $0-15 \% \mathrm{CH}_{3} \mathrm{Br}$ surfaceto-tropopause vertical gradient (Schauffler et al., 1999), the surface mixing ratio was multiplied by 0.93 ; the rest of the possible errors induced by this estimate of the tropospheric $\mathrm{CH}_{3} \mathrm{Br}$ and long-lived halons were neglected, but are expected to be small compared to the MLS error contribution.

Figure 13 shows estimates of $\mathrm{Br}_{\mathrm{y}}$ from VSLS $\left(\mathrm{Br}_{\mathrm{y}}^{\mathrm{VSLS}}\right)$ contribution to stratospheric bromine derived from $\mathrm{BrO}$ measurements as discussed in chapter 1 of WMO (2010) as well as the estimate from this study. As shown, the new MLS estimate of VSLS contribution to $\mathrm{Br}_{\mathrm{y}}$ agrees within the respective uncertainties with all the previous estimates. It also falls 
between the two previous MLS estimates $3 \pm 5.5$ (Livesey et al., 2006a) and $6.5 \pm 5.5$ pptv (Kovalenko et al., 2007). Furthermore, the new MLS estimate of VSLS contribution to $\mathrm{Br}_{\mathrm{y}}$ is in agreement with the model studies by Liang et al. (2010) and Hossaini et al. (2012) which estimate a supply of $\mathrm{Br}_{\mathrm{y}}$ from VSLS of 5 and 4.9-5.2 pptv, respectively.

\section{$7 \quad$ Summary and conclusions}

MLS zonal mean spectra divided into ascending (daytime) and descending (nighttime) were computed for each day and inverted to produce daily zonal mean $\mathrm{BrO}$ profiles from 10 to $4.6 \mathrm{hPa}$. Due to the sharp $\mathrm{BrO}$ diurnal variation, the MLS non-zero descending $\mathrm{BrO}$ abundances were used as a measure of systematic biases in the retrievals. Assuming that these biases are constant throughout day and night, we used the difference between ascending and descending $\mathrm{BrO}$ as a more accurate measure of daytime $\mathrm{BrO}$. This restricts the usable data to $50^{\circ} \mathrm{S}$ to $50^{\circ} \mathrm{N}$, avoiding the polar regions where in some seasons both ascending and descending orbits are either day (summer) or night (winter).

The vertical resolution of this dataset in the 10 to $4.6 \mathrm{hPa}$ region was found to be approximately $5 \mathrm{~km}$ (derived from the full width at half maximum, FWHM, of the averaging kernels scaled into $\mathrm{km}$ ). For this pressure range, single daily ascending-descending profile precision for a $10^{\circ}$ latitude bin was found to be up to $40 \mathrm{pptv}$ dropping to 7 and 2 pptv for monthly and yearly averages, respectively. The ascendingdescending systematic error biases were estimated to be less than $\sim 3$ pptv.

Comparisons with a SAOZ-BrO balloon flight, the SCIAMACHY and OSIRIS datasets, as well as with the SLIMCAT and WACCM models were found to agree both in structure and in $\mathrm{BrO}$ magnitude, within their uncertainties. This dataset will be made publicly available for download in a daily based NetCDF format.

Using the WACCM and SLIMCAT $\mathrm{Br}_{\mathrm{y}} / \mathrm{BrO}$ modeled ratios we infer an estimate of stratospheric $\mathrm{Br}_{\mathrm{y}}$ of $20.3 \mathrm{pptv}$ with an error due to the MLS precision, systematics errors and kinetic errors of $4.5 \mathrm{pptv}$. Assuming that the contribution of $\mathrm{CH}_{3} \mathrm{Br}$ and halons to this $\mathrm{Br}_{\mathrm{y}}$ budget was $15.6 \mathrm{pptv}$ (Montzka et al., 2003), we derive a VSLS contribution to the total $\mathrm{Br}_{\mathrm{y}}$ of $5 \pm 4.5$. This $\mathrm{Br}_{\mathrm{y}}^{\mathrm{VSLS}}$ estimate is well within the expected range found in WMO (2010, chapter 1$)$.

Acknowledgements. The research described in this paper was carried out by the Jet Propulsion Laboratory, California Institute of Technology, under contract with the National Aeronautics and Space Administration. The SLIMCAT modeling work was supported by UK NERC NCAS and NCEO. The WACCM modeling work was sponsored by the National Science Foundation and by the NASA Atmospheric Composition: Modeling and Analysis, solicitation NNH10ZDA001N-ACMAP. Vertical distributions of BrO from SCIAMACHY limb observations used in this study have been provided by the SCIAMACHY team of the Institute of Environmental Physics, University of Bremen. The provision of data and support is gratefully acknowledged. The SAOZ-balloon data was provided by F. Goutail from CNRS, France. We sincerely thanks C. A. McLinden for providing the photochemical box model output. The authors acknowledge four anonymous reviewers for their helpful comments.

Edited by: P. K. Bhartia

\section{References}

Bovensmann, H., Burrows, J. P., Buchwitz, M., Frerick, J., Noel, S., and Rozanov, V. V.: SCIAMACHY: mission objectives and measurement modes, J. Atmos. Sci., 56, 127-150, 1999.

Chipperfield, M. P.: Multiannual simulations with a threedimensional chemical transport model, J. Geophys. Res., 104, 1781-1805, 1999.

Chipperfield, M. P.: New version of the TOMCAT/SLIMCAT offline chemical transport model: intercomparison of stratospheric tracer experiments, Q. J. Roy. Meteor. Soc., 132, 1179-1203, 2006.

Dorf, M., Bösch, H., Butz, A., Camy-Peyret, C., Chipperfield, M. P., Engel, A., Goutail, F., Grunow, K., Hendrick, F., Hrechanyy, S., Naujokat, B., Pommereau, J.-P., Van Roozendael, M., Sioris, C., Stroh, F., Weidner, F., and Pfeilsticker, K.: Balloon-borne stratospheric BrO measurements: comparison with Envisat/SCIAMACHY BrO limb profiles, Atmos. Chem. Phys., 6, 2483-2501, doi:10.5194/acp-6-2483-2006, 2006.

Engel, A., Strunck, M., Müller, M., Hasse, H.-P., Poss, C., Levin, I., and Schmidt, U.: Temporal development of total chlorine in the high-latitude stratosphere based on reference distributions of mean age derived from $\mathrm{CO}_{2}$ and $\mathrm{SF}_{6}$, J. Geophys. Res., 107, 4136, doi:10.1029/2001JD000584, 2002.

Farman, J. C., Gardiner B. G., and Shanklin, J. D.: Large losses of total ozone in Antartica reveal seasonal $\mathrm{ClO}_{\mathrm{X}} / \mathrm{NO}_{\mathrm{X}}$ interaction, Nature, 315, 2007-2010, 1985.

Feng, W., Chipperfield, M. P., Dorf, M., Pfeilsticker, K., and Ricaud, P.: Mid-latitude ozone changes: studies with a 3-D CTM forced by ERA-40 analyses, Atmos. Chem. Phys., 7, 2357-2369, doi:10.5194/acp-7-2357-2007, 2007.

Garcia, R. R., Marsh, D., Kinninson, D. E., Boville, B., and Sassi, F.: Simulations of secular trends in the middle atmosphere, J. Geophys. Res., 112, D09301, doi:10.1029/2006JD007485, 2007.

Hendrick F., Johnston, P. V., De Mazière, M., Fayt, C., Hermans, C., Kreher, K., Theys, N., Thomas, A., and Van Roozendael, M.: One-decade trend analysis of stratospheric $\mathrm{BrO}$ over Harestua $\left(60^{\circ} \mathrm{N}\right)$ and Lauder $\left(45^{\circ} \mathrm{S}\right)$ reveals a decline, Geophys. Res. Lett., 35, L14801, doi:10.1029/2008GL034154, 2008.

Hossaini, R., Chipperfield, M. P., Feng, W., Breider, T. J., Atlas, E., Montzka, S. A., Miller, B. R., Moore, F., and Elkins, J.: The contribution of natural and anthropogenic very short-lived species to stratospheric bromine, Atmos. Chem. Phys., 12, 371380, doi:10.5194/acp-12-371-2012, 2012.

Kinnison, D. E., Brasseur, G. P., Walters, S., Garcia, R. R., Marsh, D. R., Sassi, F., Harvey, V. L., Randall, C. E., Emmons, L., Lamarque, J. F., Hess, P., Orlando, J. J., Tie, X. X., Randel, W., Pan, L. L., Gettelman, A., Granier, C., Diehl, T., 
Niemeier, U., and Simmons, A. J.: Sensitivity of chemical tracers to meteorological parameters in the MOZART-3 chemical transport model, J. Geophys. Res., 112, D20302, doi:10.1029/2006JD007879, 2007.

Kovalenko, L., Livesey, N., Salawitch, R., Camy-Peyret, C., Chipperfield, M., Cofield, R., Dorf, M., Drouin, B., Froidevaux, L., Fuller R., Goutail, F., Jarnot, R., Jucks, K., Knosp B., Lambert, A., MacKenzie, I., Pfeilsticker, K., Pommereau, J., Read, W., Santee, M., Schwartz, M., Snyder, W., Stachnik, R., Stek, P., Wagner, P., and Waters, J.: Validation of Aura Microwave Limb Sounder BrO observations in the stratosphere, J. Geophys. Res., 112, D24S41, doi:10.1029/2007JD008817, 2007.

Lamarque, J.-F., Emmons, L. K., Hess, P. G., Kinnison, D. E., Tilmes, S., Vitt, F., Heald, C. L., Holland, E. A., Lauritzen, P. H., Neu, J., Orlando, J. J., Rasch, P. J., and Tyndall, G. K.: CAM-chem: description and evaluation of interactive atmospheric chemistry in the Community Earth System Model, Geosci. Model Dev., 5, 369-411, doi:10.5194/gmd-5-369-2012, 2012.

Liang, Q., Stolarski, R. S., Kawa, S. R., Nielsen, J. E., Douglass, A. R., Rodriguez, J. M., Blake, D. R., Atlas, E. L., and Ott, L. E.: Finding the missing stratospheric Bry: a global modeling study of $\mathrm{CHBr}_{3}$ and $\mathrm{CH}_{2} \mathrm{Br}_{2}$, Atmos. Chem. Phys., 10, 2269-2286, doi:10.5194/acp-10-2269-2010, 2010.

Llewellyn, E., Lloyd, N., Degenstein, D., Gattinger, R., Petelina, S., Bourassa, A., Wiensz, J., Ivanov, E., McDade, I., Solheim, B., McConnell, J., Haley, C., von Savigny, C., Sioris, C., McLinden, C., Grifoen, E., Kaminski, J., Evans, W., Puckrin, E., Strong, K., Wehrle, V., Hum, R., Kendall, D., Matsushita, J., Murtagh, D., Brohede, S., Stegman, J., Witt, G., Barnes, G., Payne, W., Pich, L., Smith, K., Warshaw, G., Deslauniers, D.L., Marchand, P., Richardson, E., King, R., Wevers, I., McCreath, W., Kyrl, E., Oikarinen, L., Leppelmeier, G., Auvinen, H., Mgie, G., Hauchecorne, A., Lefvre, F., de La Ne, J., Ricaud, P., Frisk, U., Sjoberg, F., von Schele, F., and Nordh, L.: The OSIRIS instrument on the Odin spacecraft, Can. J. Phys., 82, 411-422, 2004.

Livesey, N., Kovalenko L., Salawitch, R., MacKenzie, I., Chipperfield, M., Read, W., Jarnot, R., and Waters, J.: EOS microwave limb sounder observations of upper stratospheric BrO: implications for total bromine, Geophys. Res. Lett., 33, L20817, doi:10.1029/2006GL026930, 2006a.

Livesey, N., Snyder, W. V., Read, W. G., and Wagner, P.: Retrieval Algorithms for the EOS Microwave Limb Sounder (MLS), IEEE T. Geosci. Remote, 44, 1144-1155, 2006b.

McLinden, C. A., Olsen, S. C., Hannegan, B., Wild, O., Prather, M. J., and Sundet, J.: Stratospheric ozone in 3-D models: A simple chemistry and the cross-tropopause flux, J. Geophys. Res., 105, 14653-14665, 2000.

McLinden, C. A., Haley, C. S., Lloyd, N. D., Hendrick, F., Rozanov, A., Sinnhuber, B.-M., Goutail, F., Degenestein, D. A., Llewellyn, E. J., Sirios, C. E., Roozendael, M. V., Pommereau, J. P., Lotz, W., and Burrows, P.: Odin/OSIRIS observations of stratospheric BrO: retrieval methodology, climatology, and inferred $\mathrm{Br}_{\mathrm{y}}$, J. Geophys. Res., 115, D15308, doi:10.1029/2009JD012488, 2010.

Montzka, S. A., Butler, J. H., Hall, B. D., Mondeel, D. J., and Elkins, J. W.: A decline in tropospheric organic bromine, Geophys. Res. Lett., 30, 1826, doi:10.1029/2003GL017745, 2003.
Prather, M.: Catastrophic Loss of Stratospheric Ozone in Dense Volcanic Clouds, J. Geophys. Res., 97, 10187-10191, 1992.

Pundt, I., Pommereau, J.-P., Chipperfield, M. P., Van Roozendael M., and Goutail, F.: Climatology of the stratospheric BrO vertical distribution by balloon-borne UV-visible spectrometry, J. Geophys. Res., 107, 4806, doi:10.1029/2002JD002230, 2002.

Read, W., Lambert, A., Bacmeister, J., Cofield, R. E., Christensen, L. E. Cuddy, D. T., Daffer, W. H., Drouin, B. J., Fetzer, E., Froidevaux, L., Fuller, R., Herman, R., Jarnot, R. F., Jiang, J. H., Jiang, Y. B., Kelly, K., Knosp, B. W., Kovalenko, L. J. Livesey, N. J., Liu, H.-C., Manney, G. L., Pickett, H. M., Pumphrey, H. C., Rosenlof, K. H., Sabounchi, X., Santee, M. L., Schwartz, M. J., Snyder, W. V., Stek, P. C., Su, H. S., Takacs, L. L., Thurstans, R. P., Vömel, H., Wagner P. A., Waters, J. W., Webster, C. R., Weinstock, E. M., and Wu, D. L.: Aura microwave limb sounder upper tropospheric and lower stratospheric $\mathrm{H}_{2} \mathrm{O}$ and relative humidity with respect to ice validation, J. Geophys. Res., 112, D24S35, doi:10.1029/2007JD008752, 2007.

Rodgers, C.: Inverse Methods for Atmospheric Sounding: Theory and Practice, Series on Atmospheric, Oceanic and Planetary Physics, Vol. 2, World Scientific, Singapore, 2000.

Rozanov, A., Kühl, S., Doicu, A., McLinden, C., Puķite, J., Bovensmann, H., Burrows, J. P., Deutschmann, T., Dorf, M., Goutail, F., Grunow, K., Hendrick, F., von Hobe, M., Hrechanyy, S., Lichtenberg, G., Pfeilsticker, K., Pommereau, J. P., Van Roozendael, M., Stroh, F., and Wagner, T.: BrO vertical distributions from SCIAMACHY limb measurements: comparison of algorithms and retrieval results, Atmos. Meas. Tech., 4, 1319-1359, doi:10.5194/amt-4-1319-2011, 2011.

Sander, S. P., Friedl, R. R., Ravishankara, A. R., Golden, D. M., Kolb, C. E., Kurylo, M. J., Huie, R. E., Orkin, V. L., Molina, M. J., Moortgat, G. K., and Finlaysson-Pitts, B. J.: Chemical kinetics and photochemical data for use in atmospheric studies, Evaluation 14, JPL Publ., 02-25, Jet Propulsion Laboratory, Pasadena, California, 2003.

Sander, S. P., Friedl, R. R., Ravishankara, A. R., Golden, D. M., Kolb, C. E., Kurylo, M. J., Molina, M. J., Moortgat, G. K., KellerRudek, H., Finlaysson-Pitts, B. J., Wine, P. H., Huie, R. H., and Orkin, V. L.: Chemical kinetics and photochemical data for use in atmospheric studies, Evaluation number 15, JPL Publ. 06-2, Jet Propulsion Laboratory, Pasadena, California, 2006.

Sander, S. P., Friedl, R. R., Abbatt, J. P. D., Barker, J. R., Burkholder, J. B., Golden, D. M., Kolb, C. E., Kurylo, M. J., Moortgat, G. K., Wine, P. H., Huie, R. E., and Orkin, V. L.: Chemical Kinetics and Photochemical Data for Use in Atmospheric Studies, Evaluation Number 17, JPL Publication 10-6 Jet Propulsion Laboratory, Pasadena, California, 2011.

Salawitch, R. J., Weisenstein, D. K., Kovalenko, L. J., Sioris, C. E., Wennberg, P. O., Chance, K., Ko, M. K. W., and McLinden, C. A.: Sensitivity of ozone to bromine in the lower stratosphere, Geophys. Res. Lett., 32, L05811, doi:10.1029/2004GL021504, 2005.

Salawitch, R. J., Canty, T., Kurosu, T., Chance, K., Liang, Q., da Silva, A., Pawson, S., Nielsen, J. E., Rodriguez, J. M., Bhartia, P. K., Liu, X., Huey, L. G., Liao, J., Stickel, R. E., Tanner, D. J., Dibb, J. E., Simpson, W. R., Donohoue, D., Weinheimer, A., Flocke, F., Knapp, D., Montzka, D., Neuman, J. A., Nowak, J. B., Ryerson, T. B., Oltmans, S., Blake, D. R., 
Atlas, E. L., Kinnison, D. E., Tilmes, S., Pan, L. L., Hendrick, F., Van Roozendael, M., Kreher, K., Johnston, P. V., Gao, R. S., Johnson, B., Bui, T. P., Chen, G., Pierce, R. B., Crawford, J. H., and Jacob, D. J.: A new interpretation of total column BrO during Arctic spring, Geophys. Res. Lett., 37, L21805, doi:10.1029/2010GL043798, 2010.

Schauffler, S. M., Atlas, E. L., Blake, D. R., Flocke, F., Lueb, R. A., Lee-Taylor, J. M., Stroud, V., and Travnicek, W.: Distributions of brominated organic compounds in the troposphere and lower stratosphere, J. Geophys. Res. 104, 21513-21535, 1999.

Schofield R., Kreher, K., Connor, B. J., Johnston, P. V., Thomas, A., Shooter, D., Chipperfield, M. P., Rodgers, C. D., and Mount,G. H.: Retrieved tropospheric and stratospheric BrO columns over Lauder, New Zealand, J. Geophys. Res., 109, D14304, doi:10.1029/2003JD004463, 2004.

Schofield, R., Johnston, P. V., Thomas, A., Kreher, K., Connor, B. J., Wood, S., Shooter, D., Chipperfield, M. P., Richter, A., von Glasow, R., and Rodgers, C. D.: Tropospheric and stratospheric BrO columns over Arrival Heights, Antarctica, 2002, J. Geophys. Res., 111, D22310, doi:10.1029/2005JD007022, 2006.

Sinnhuber, B.-M., Arlander, D. W., Bovensmann, H., Burrows, J. P., Chipperfield, M. P., Enell, C.-F., Frieß, U., Hendrick, F., Johnston, P. V., Jones, R. L., Kreher, K., Mohamed-Tahrin, N., Müller, R., Pfeilsticker, K., Platt, U., Pommereau, J.-P., Pundt, I., Richter, A., South, A. M., Tørnkvist, K. K., Van Roozendael, M., Wagner, T., and Wittrock, F.: Comparison of measurements and model calculations of stratospheric bromine monoxide, J. Geophys. Res., 107, 4398, doi:10.1029/2001JD000940, 2002.

Sinnhuber, B.-M., Rozanov, A., Sheode, N., Afe, O. T., Richter, A., Sinnhuber, M., Wittrock, F., and Burrows, J. P.: Global observations of stratospheric bromine monoxide from SCIAMACHY, Geophys. Res. Lett., 32, L2081, doi:10.1029/2005GL023839, 2005.

Sinnhuber, B.-M., Sheode, N., Sinnhuber, M., Chipperfield, M. P., and Feng, W.: The contribution of anthropogenic bromine emissions to past stratospheric ozone trends: a modelling study, Atmos. Chem. Phys., 9, 2863-2871, doi:10.5194/acp-9-2863-2009, 2009.

Sioris, C. E., Kovalenko, L. J., McLinden, C. A., Salawitch, R. J., Van Roozendael, M., Goutail, F., Dorf, M., Pfeilsticker, K., Chance, K., von Savigny, C., Liu, X., Kurosu, T. P., Pommereau, J.-P., Bösch, H., and Frerick, J.: Latitudinal and vertical distribution of bromine monoxide in the lower stratosphere from Scanning Imaging Absorption Spectrometer for Atmospheric Chartography limb scattering measurements, J. Geophys. Res., 111, D14301, doi:10.1029/2005JD006479, 2006.
Soller, R., Nicovich, J. M., and Wine, P. H.: Temperature-dependent rate coefficients for the reactions of $\left.\mathrm{Br}\left({ }^{2} P_{3 / 2}\right), \mathrm{Cl}^{2}{ }^{2} P_{3 / 2}\right)$, and $\mathrm{O}\left({ }^{3} P_{J}\right)$ with $\mathrm{BrONO}_{2}$, J. Phys. Chem. A, 105, 1416-1422, 2001.

Sugita, T., Kondo, Y., Nakajima, H., Schmidt, U., Engel, A., Oelhaf, H., Wetzel, G., Koike, M., and Newman, P. A.: Denitrification observed inside the Arctic vortex in February 1995, J. Geophys. Res., 103, 16221-16233, 1998.

Theys, N., Van Roozendael, M., Hendrick, F., Fayt, C., Hermans, C., Baray, J.-L., Goutail, F., Pommereau, J.-P., and De Mazière, M.: Retrieval of stratospheric and tropospheric BrO columns from multi-axis DOAS measurements at Reunion Island $\left(21^{\circ} \mathrm{S}\right.$, $56^{\circ}$ E), Atmos. Chem. Phys., 7, 4733-4749, doi:10.5194/acp-74733-2007, 2007.

Wamsley, P. R., Elkins, J. W., Fahey, D. W., Dutton, G. S., Volk, C. M., Myers, R. C., Montzka, S. A., Butler, J. H., Clarke, A. D., Fraser, P. J., Steele, L. P., Lucarelli, M. P., Atlas, E. L., Schauffler, S. M., Blake, D. R., Rowland, F. S., Sturges, W W. T., Lee, J. M., Penkett, S. A., Engel, A., Stimpfle, R. M., Chan, K. R., Weisenstein, D. K., Ko, M. K. W., and Salawitch, R. J.: Distribution of halon-1211 in the upper troposphere and lower stratosphere and the 1994 total bromine budget, J. Geophys. Res., 103, 1513-1526, 1998.

Waters, J., Read, W., Froidevaux, L., Jarnot, R., Cofield, R., Flower, D., Lau, G., Pickett, H., Santee, M., Wu, D., Boyles, M., Burke, J., Lay, R., Loo, M., Livesey, N., Lungu, T., Manney, G., Nakamura, L., Perun, V., Ridenoure, B., Shippony, Z., Siegel, P., Thurstans, R., Harwood, R., and Filipiak, M.: The UARS and EOS microwave limb sounder experiments, J. Atmos. Sci., 56, 194-218, 1999.

Waters, J., Froidevaux, L., Harwood, R., Jarnot, R., Pickett, H., Read, W., Siegel, P., Cofield, R., Filipiak, M., Flower, D., Holden, J., Lau, G., Livesey, N., Manney, G., Pumphrey, H., Santee, M., Wu, D., Cuddy, D., Lay, R., Loo, M., Perun, V., Schwartz, M., Stek, P., Thurstans, R., Boyles, M., Chandra, S., Chavez, M., Chen, G.-S., Chudasama, B., Dodge, R., Fuller, R., Girard, M., Jiang, J., Jiang, Y., Knosp, B., LaBelle, R., Lam, J., Lee, K., Miller, D., Oswald, J., Patel, N., Pukala, D., Quintero, O., Scaff, D., Snyder, W., Tope, M., Wagner, P., and Walch, M.: The Earth Observing System Microwave Limb Sounder (EOS MLS) on the aura satellite, IEEE T. Geosci. Remote, 44, 1075-1092, doi:10.1109/TGRS.2006.873771, 2006.

World Meteorological Organization: Scientific Assessment of Ozone Depletion: 2010, Global Ozone Research and Monitoring Project - Report No. 52, Geneva, Switzerland, 2010. 